\title{
German enterprises and the changes in energy economics due to increased concerns regarding environmental sustainability
}

\author{
Gregor WEBER
}

\author{
Bucharest University of Economic Studies, Romania
}

\begin{abstract}
This article is part of a first year doctoral research regarding the current state of knowledge in environmental sustainability, energy economics and their impact on European enterprises. As the current changes and modifications of the German energy economics system are observed by people all around the globe, the current paper analyzes what has been said until now in the scientific literature on character of the new strategy for energy consumption and production in Germany and its impact on environmental and social sustainability. With the help of two questionnaire-based surveys conducted in 2013 and 2014 through the German DIHK', German enterprises were surveyed in order to: identify potential differences and similarities between the two periods, identify the effects of the energy transition on companies' profitability, and analyze these effects and compare the results in terms of potential trend developments. The research findings confirmed that changes in the energy system affect not only the environmental sustainability only, but also the economy, in some cases even independent of the stage in which the changing system of the economy presently is.
\end{abstract}

Keywords: environmental sustainability, social sustainability, energy efficiency, sustainable development, enterprise competitiveness, electricity price, energy economics

Please cite the article as follows: Weber, G. (2015), "German enterprises and the changes in energy economics due to increased concerns regarding environmental sustainability", Management \& Marketing. Challenges for the Knowledge Society, Vol. 10, No. 1, pp. 72-89, DOI: $10.1515 /$ mmcks-2015-0006.

\section{Introduction}

The energy economy in Germany is currently undergoing a major change, represented by the shift from fossil and nuclear energy supply to a sustainable energy production in the electricity, heat and mobility sectors. In this process, Germany is the only nation worldwide that is going through such a radical change in such a short time - by that Germany is the testing laboratory for the reconstruction of the entire world energy system. This energy transition targets, on the one hand, a reduction of the greenhouse gas emissions (for climate protection) and the reduction of the risks of nuclear power production (environmental and social sustainability) and, on the other hand, a sustainable use of the available energy resources. The push for renewable energies, energy savings (e.g., insulation of buildings) and improved energy efficiency (e.g., cogeneration of heat and power) are hereby vital parts of the energy transition; smart grids and smart meters are also important in order to drive a successful load management.

The energy transition in Germany started long before the Fukushima nuclear catastrophe. In 1997 the EU policy for the privatization of the power industry had been already included into the national law (Kemfert, 2013) and

Correspondence: Gregor Weber weber@renervis. com

\footnotetext{
${ }^{1}$ German DIHK (Deutscher Industrie- und Handelskammertag): Association of German Chambers of Commerce and Industry
} 
since then, several other changes were implemented, such as the separation of the grid management from power production. This was a paradigm shift from the traditional power supply. Finally, in 2009, the German government decided to develop a national energy concept, which was put in action one year later. In March 2011, after the Fukushima incident, the German government had the German nuclear plants undergo a stress test. In May 2011, the government announced the pull-off from the nuclear energy until 2022 and the systematical expansion of renewable energies.

Since then, the law regarding renewable energies had to undergo several changes concerning the support for renewable energy plants (see also Marin, 2013, p.729). Laws were also elaborated to promote any activities related to energy efficiency. As of 2013, energy management systems are mandatory for large enterprises in Germany considering applying for refunds on electricity and energy taxes; as of 2015, this regulation will be intensified by adding the companies' obligation to prove true energy savings.

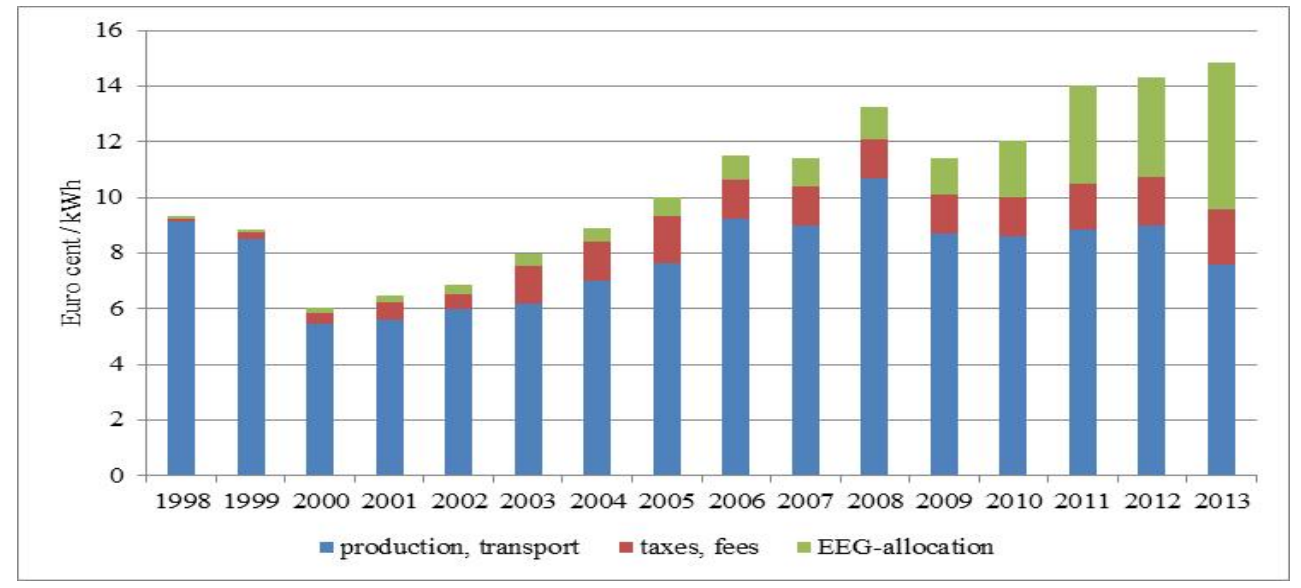

Figure 1: Development of the average electricity price for the German industry Source: Author's design based on data taken from bdew (2013, p. 14).

With the introduction of renewable energies in Germany, the EEG (law for renewable energies) defined the feed-in tariffs. The EEG-allocation was introduced in order to finance the feed-in-tariff system. The top bars in Figure 1 hereby visualize the share of the EEG-allocation in the electricity price. In the actual political debate in Germany, the remodelling of the EEG is being discussed, in order to limit the yearly increases in electricity prices to a certain level, which gets the feed-in-tariff-system under pressure.

The pressure on the German industry is being strongly debated in the context of the uncompetitivness of the electricity prices in the industry amongst its European partners. A comparison of the electrity tax level conducted by the BDI (German association of the industry) in 2011 (BDI \& VCI, 2011, p. 31) highlights Germany with a substantial electricity tax disadvantage to its partners. In order not to overstress companies, exemptions from the EEG-allocation were approved by the German government for those companies with large electricity consumption to help them stay internationally competitive. Consequently, the remaining companies and public consumers have to compensate the value of these exemptions. The European Commission recently opened a case against the German government with the objective to evaluate whether the exemptions to the EEG- 
MMCKS allocation give a competitive advantage to German companies in the European context.

While large companies often have the means, capacity, financial reserves and lobbyists to adapt to such changes one way or the other, small and medium sized enterprises have a hard time coping with changes in their running cost, and usually cannot benefit from exceptions to energy taxes which are often enough accorded to large companies. SMEs are socially and economically the dominating size of companies. According to the European Commission, SMEs count in the EU (European Union) for $99 \%$ of all enterprises and offer jobs to 65 Mio people. SMEs are the essential motor for innovation and the foundation for any national economy (DIHK, 2013, p. 22). In the case of the German industry, the share on the value creation of the total economy is at $24 \%$, one of the highest in Europe. Any negative impact on the financial health of the SME sector is to be carefully analyzed and taken serious as it would result in a negative impact of the national economy.

\section{Energy price comparison for Germany within Europe}

When comparing the German electricity prices with the rest of Europe we need to differentiate between large, middle and low consumers (Figure 2). In comparison with the situation in Romania, for instance, for low consumers the electricity prices in Germany are more than double (202\%) the Romanian level. This is caused to a large extent by the earlier explained exemption regulations from the EEGallocation for large consumers in Germany; consumers which do not benefit from an exception have to compensate the financial benefits of the ones with an exemption. For large and middle consumers the difference is not as high, but the electricity price for German companies is still more than $50 \%$ higher compared to the respective price levels for the Romanian companies.

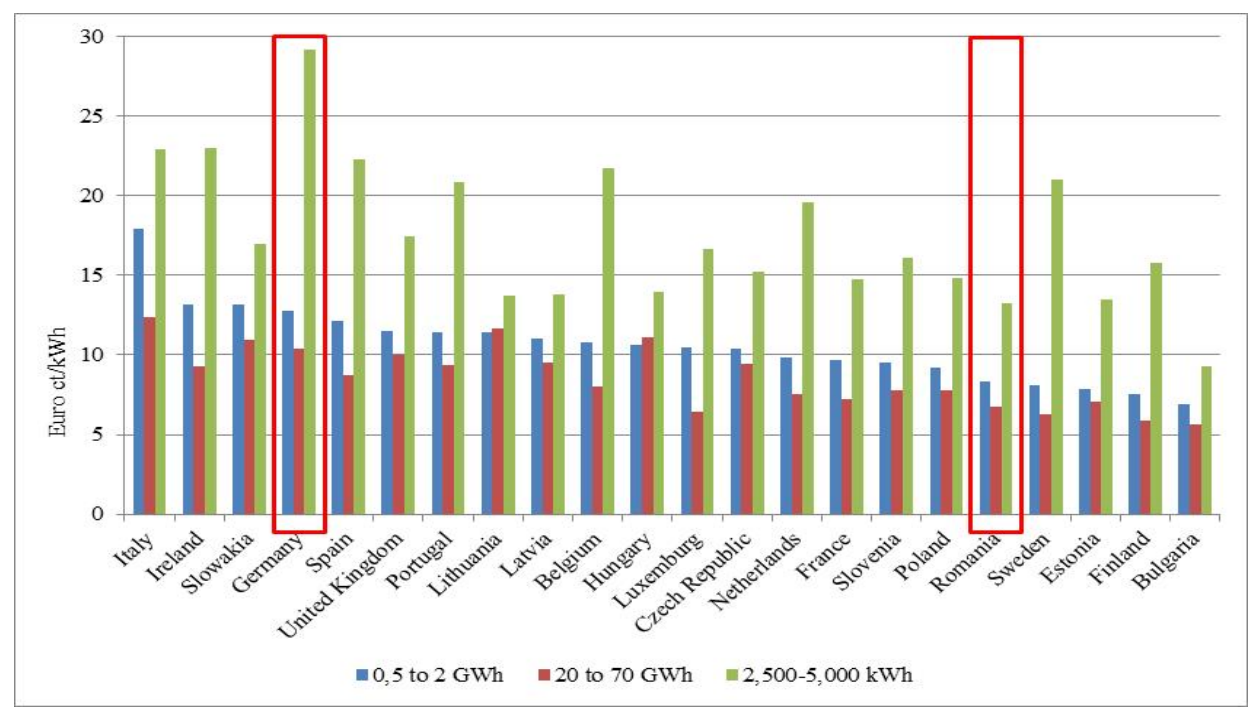

Figure 2: Electricity prices in Europe by consumption clusters, Germany and Romania highlighted

Source: Author's design based on data taken from statista (2012) and bdew (2013, p. 14)

Comparing the production cost for electricity, renewable energies have a clear cost advantage versus the fossil power plants (Fraunhofer ISE, 2013). However, the lower the production cost of the renewable gets, the higher goes the 
end price for electricity to the consumer at the electricity exchange, caused by the MMCKS merit-order-effect (ewi, 2012).

The same situation as in the case of the electricity price levels, the German industry pays double the price for gas in the Romanian industry which is here taken as an example. The situation is exemplified in Figure 3 where the red horizontal line marks the difference between the two price levels.

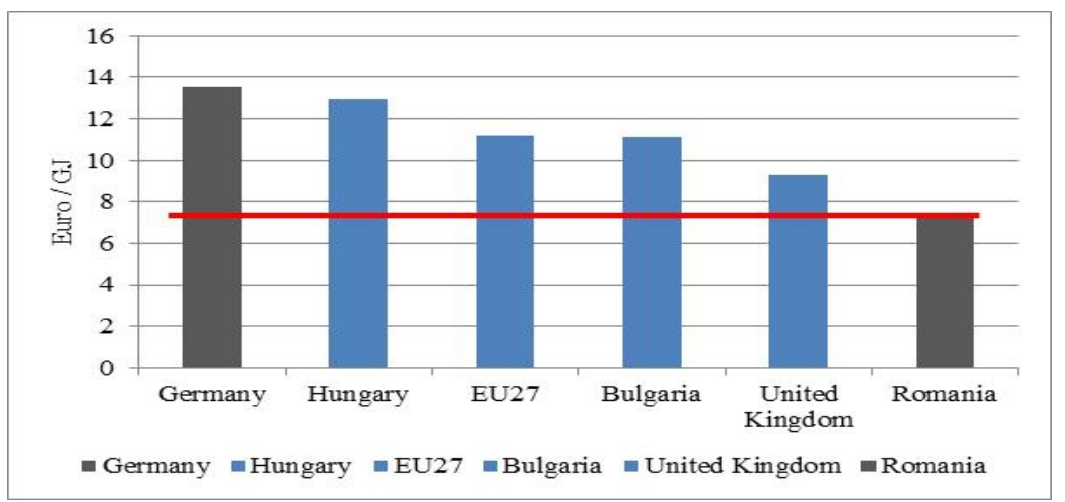

Figure 3: Gas prices in selected European countries (w/o VAT), highlighted for Germany and Romania

Source: Author's design based on data taken from AHK Germany-Romania (2013, p. 22)

\section{The energy transition in Germany}

In view of a constantly growing world population, the human race will only be able to ensure its current level of economic wealth if economic growth goes along with a reduced use of short and expensive resources and this includes energy. Economic growth needs to be disconnected from the wastage of fossil resources and shifted towards the integration of renewable energies.

This will not only ensure a more cost effective production of future energy, but, at the same time, it will reduce the level of the so called "social costs". These burden the national economies through increasing health costs (for example: the pollution from coal and nuclear power plants leads to increased rates of cancer occurrences which are a cost driver for the health system), increasing cost of coping with the forces of nature which will become more and more extreme, the cost caused by the increasing emission of greenhouse gas etc. Hence there are good reasons for the energy transition, which can be summarized as follows: (a) responsibility towards future generations; (b) climate protection and nature preservation; (c) security of supply (in general, not just of energy), competitiveness and cost stability; (d) booster for economic growth and employment (BMU, 2012a, 2012b); (e) and the increased level of public participation.

The German government presented in 2010 for the first time a long-term strategy for the energy transition. The strategy includes giving up nuclear energy, the expansion of the renewable energies and, most importantly, measures for the increase in energy efficiency and the reduction of greenhouse gases. This energy transition decision in Germany is based on several studies and scenarios performed by scientific institutes such as the Institute for Ecology, Prognos AG (Prognos, ewi, gws, 2010) and others. These reports indicate whether and in which context the German energy transition can be realized. Most of these studies were authorized by the German government, namely the Ministries of Environment (BMU), Economy (BMWi, 2013, 2014) or Finance (BMF). 
MMCKS The energy scenarios in the energy strategy of the German government (Prognos, ewi, gws, 2010,) confirm that the planned change to produce energy primarily from renewable resources by 2050 is technically realizable with the current technical knowledge. It is also confirmed that compared to other energy sourcing strategies this process also offers benefits to the national economy and that the "energy transition" and the protection of the environment go together (BMU, 2013a, 2013b). Additional studies from different sponsors confirm the technological as well the economic feasibility of the targets defined by the energy strategy of the government. Some of them even consider a $100 \%$ switch to renewable energies feasible (the Federal Office of Environment, the German DLR, and the Governmental Expert Commission Environment SRU - Ökoinstitut e. V., Prognos, 2009; SRU - Sachverständigenrat für Umweltfragen, 2011; DLR, Fraunhofer IWES, IfnE, 2010; Umweltbundesamt, 2010; Bundesregierung, 2010; SRU, 2013; ZNES, 2011). The advanced pullout from the nuclear power was also examined in detail, especially after the reactor disaster of Fukushima in March 2011. The securing of electricity supply and grid stability at a high quality level were the most important elements and, as such, the focus areas of the studies following "Fukushima". Electricity costs, greenhouse gas development and the projected electricity imports were also investigated (BET, 2010; ZNES (Zentrum für nachhaltige Energiesysteme, 2011; Greenpeace, 2011; R2B, 2011; Ökoinstitut e. V., 2010). All these studies confirmed that the combination of the capacities of the renewable energy power plants together with those of the fossil power plants (existing plus under construction) will be able to substitute the switch-off of the nuclear power plants in Germany. They also confirmed that there will be challenges which can be addressed through grid expansion and modernization of the grid infrastructure.

Going through all the studies and researches performed so far, there was no investigation regarding the correlation between changes in the energy system and its impact on the industry. In order to fill this gap, the Association of German Chambers of Commerce and Industry (Deutscher Industrie- und Handelskammertag, DIHK (DIHK, 2014)) representing 80 Chambers of Commerce and Industry, CCI (Industrie- und Handelskammern, IHKs) in Germany with more than three million entrepreneurs of companies of all sizes, surveyed its members with specific questions related to the ongoing changes in the energy economics in June 2013 and June 2014. The result were 2,394 answered questionnaires in 2013 and 2,193 in 2014, which are the basis of an intense research and analysis on the impacts of changes in the energy system on the industry.

\section{Research methodology}

The present study sampled enterprises in Germany. The first part of the questionnaire contained general data about the enterprises, such as branch of activity, number of employees, the share of the energy cost, in general, and the electricity cost, in particular, in the overall turnover, as well as the general judgment of the changes in the energy economics. The remaining questions were clustered into four sections, asking on about: (a) the importance of the selected factors during the last twelve months; (b) measures and activities the company is implementing as a result of changes in the economics of energy; (c) the use of electricity provided by own production capacities; (d) measures with effects on the outside world the company is undertaking as a result of changes in the energy 
economy. Finally the companies were asked to rate selected political measures to make the energy supply secure, payable and environmentally friendly.

The data was analyzed using the following clusters (Figure 4): (a) 2013 companies in general; (b) 2013 companies clustered according to their size; (c) companies clustered according to their branch; (d) companies in general; (e) 2014 companies clustered according to their size; (f) 2014 companies clustered according to their branch; (g) comparison between 2013 and 2014 companies in general; (h) comparison between 2013 and 2014 companies clustered according to their size; (g) comparison between 2013 and 2014 companies clustered according to their branch.

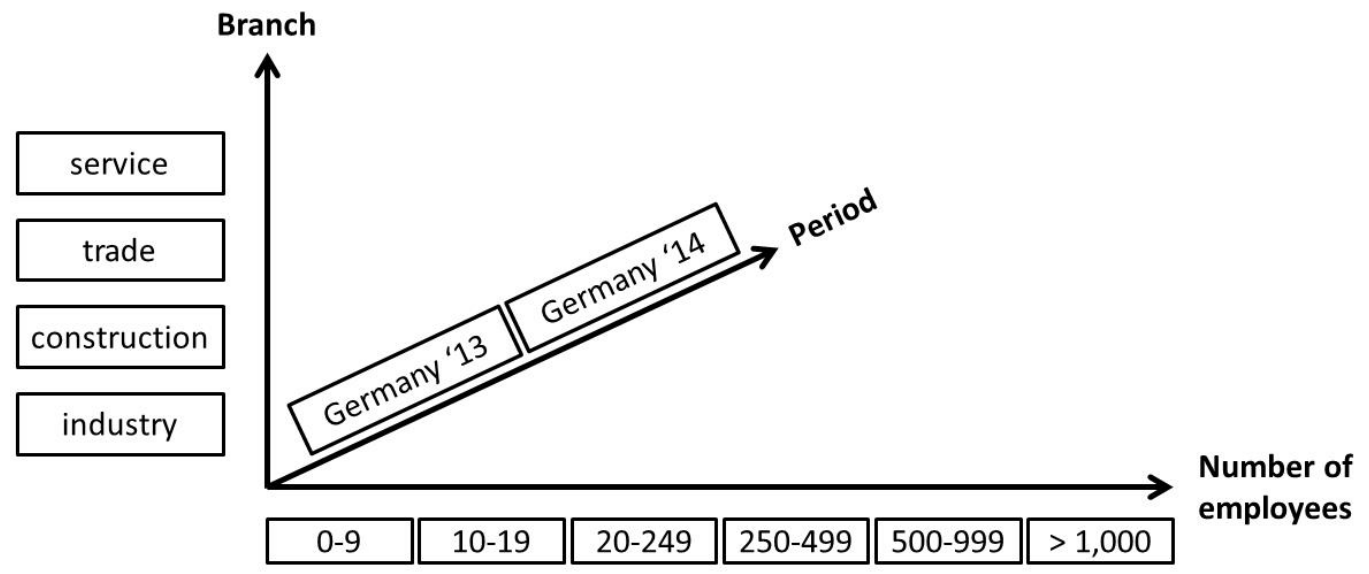

Figure 4: Three-dimensional clustering methodology

Source: Author's own contribution.

For this paper, the first cluster (a) listed in the questionnaire was analyzed, addressing the importance of changes of several aspects of the energy supply over a twelve month period. Energy supply was divided into six factors namely electricity price, energy price, fluctuation in energy price, energy savings, disturbances in electricity supply and gas supply. All these items were rated on a four point Likert Scale (Christof and Pepels, 1999,) ranging from "don't know" (1) to "increased" (4) evaluating the importance of the six aspects mentioned. In addition, the respondents were asked about the existence of problems regarding the security of energy supplies and, in case of a positive answer, they were asked about the duration and the resulting financial loss.

The literature offers a variety of techniques for data evaluation (Koch, 2012; Herrmann and Homburg, 2000; Olbrich et al., 2012; Christof and Pepels, 1999; Grunwald and Hempelmann, 2012; Altobelli and Hoffmann, 2011; Homburg and Krohmer, 2009; Wöhe, 1986; Kotler, 1982). The research elements can be either qualitative or quantitative. This paper is focused on the quantitative methodology (Koch, 2012). The collected data are analyzed using the methodology of the one dimensional frequency scale, in order to identify the focus areas indicated by the enterprises as important elements resulting from the changes in the energy economics (ref. Error! Reference source not found.). 
Table 1. Overview of descriptive analysis methods

\begin{tabular}{|c|c|c|c|}
\hline & & & \\
\hline & uni-variate data analysis & bi-variate data analysis & multi-variate data analysis \\
\hline Frequency analysis & $\begin{array}{l}\text { Localization parameter } \\
\text { - Dispersion parameter } \\
\text { Form parameter } \\
\text { Concentration parameter }\end{array}$ & & \\
\hline Dependency analysis & & $\begin{array}{l}\text { Contingency analysis } \\
\text { Regression analysis }\end{array}$ & $\begin{array}{l}\text { Variance analysis } \\
\text { Discriminant analysis } \\
\text { Contrast group analysis } \\
\text { Conjoint measurement }\end{array}$ \\
\hline Correlation analysis & & $\begin{array}{l}\text { Correlation analysis } \\
\text { Coefficient of determination }\end{array}$ & $\begin{array}{l}\text { Factor analysis } \\
\text { Cluster analysis } \\
\text { Multidimensional Scaling } \\
\text { Causal analysis }\end{array}$ \\
\hline
\end{tabular}

Source: adapted from Christof and Pepels (1999, p. 63) and Herrmann and Homburg (2000, pp. 107-123).

The determined frequencies are usually visualized using frequency polygons, bar diagrams, circle diagrams, or pillar diagrams (Herrmann and Homburg, 2000) - the latter are the ones used in this paper. In a second step, we analyzed correlations, in order to identify the interactions among the individual elements investigated in the questionnaires. These were substantiated using causal relations and verifications. Causal models represent the correlation respectively the assumptions of cause-and-effect chains.

\section{Research results}

Descriptive statistics

A first analysis of the questionnaires referred to the mixture of branches of the participating companies in both years (Figure ), which are industry, construction, trade and service. In both years the company branch mix shows the strongest shares for industry and service. Whereas the participation of the industry sector increased from 2013 to 2014 by 5.5\%, all other sectors were slightly less represented in 2014. 


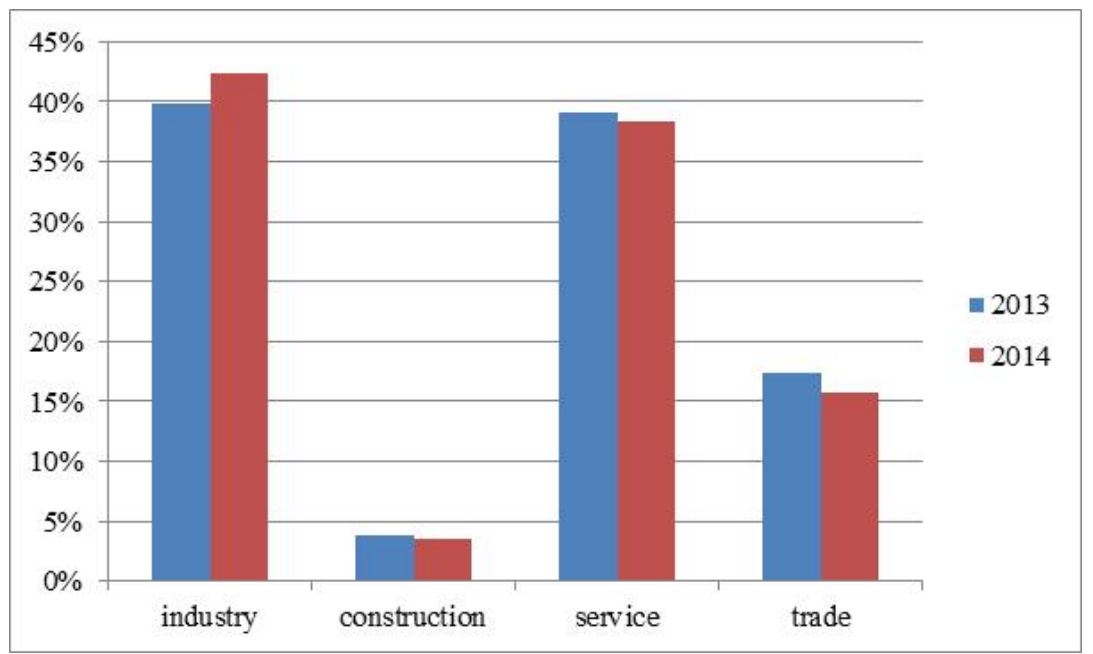

MMCKS

Figure 5: The economic sectors of the respondent enterprises in 2013 and 2014

Source: Author's own research.

Also part of the first analysis was the share of the number of employees of the companies. As Figure illustrates, SMEs (0-249 employees) were with $73.4 \%$ (in 2013) and $72 \%$ (in 2014) the strongest group in both years. In both years, the largest group within the SMEs was the group with 20-249 employees. The larger enterprises were grouped within a range from $6 \%$ to $11 \%$.

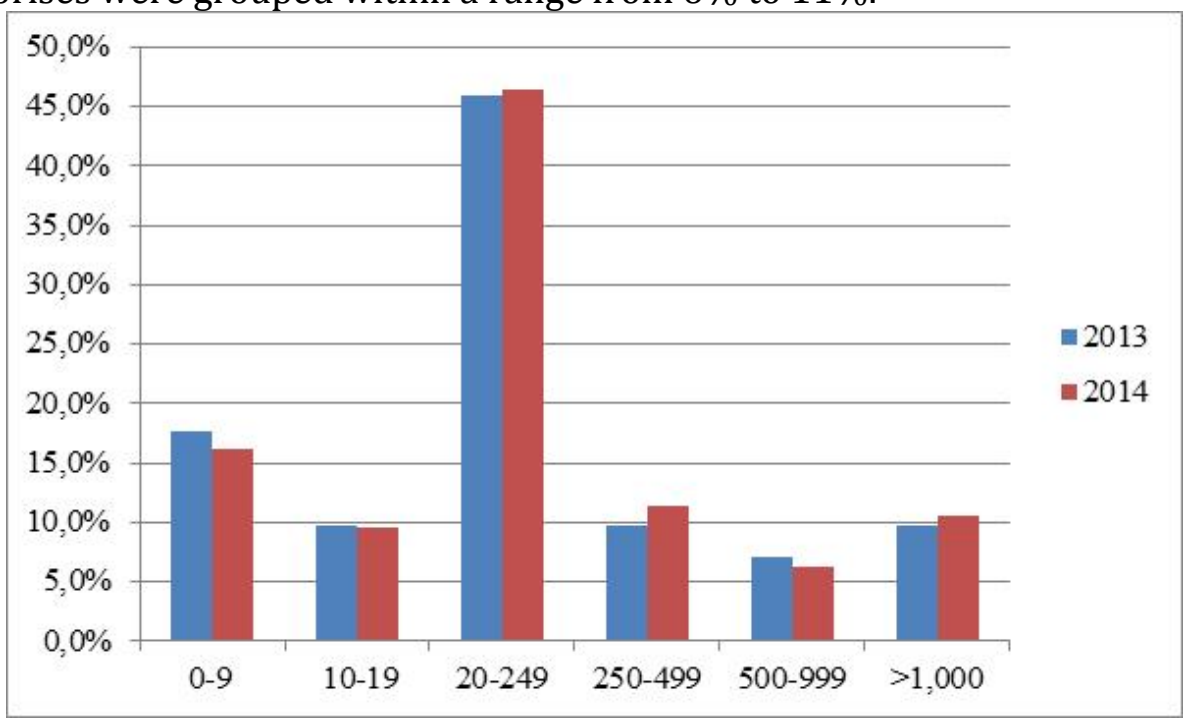

Figure 6: Share of the respondent enterprises according to the number of employees

Source: Author's own research.

Whereas the share of the energy cost in the overall turnover (Figure ) was almost equally spread in the given ranges $(0-2 \%, 2-4 \%, 4-14 \%)$, the group of $>14 \%$ was only around one third compared to the other 3 groups. No significant differences between 2013 and 2014 could be identified. 


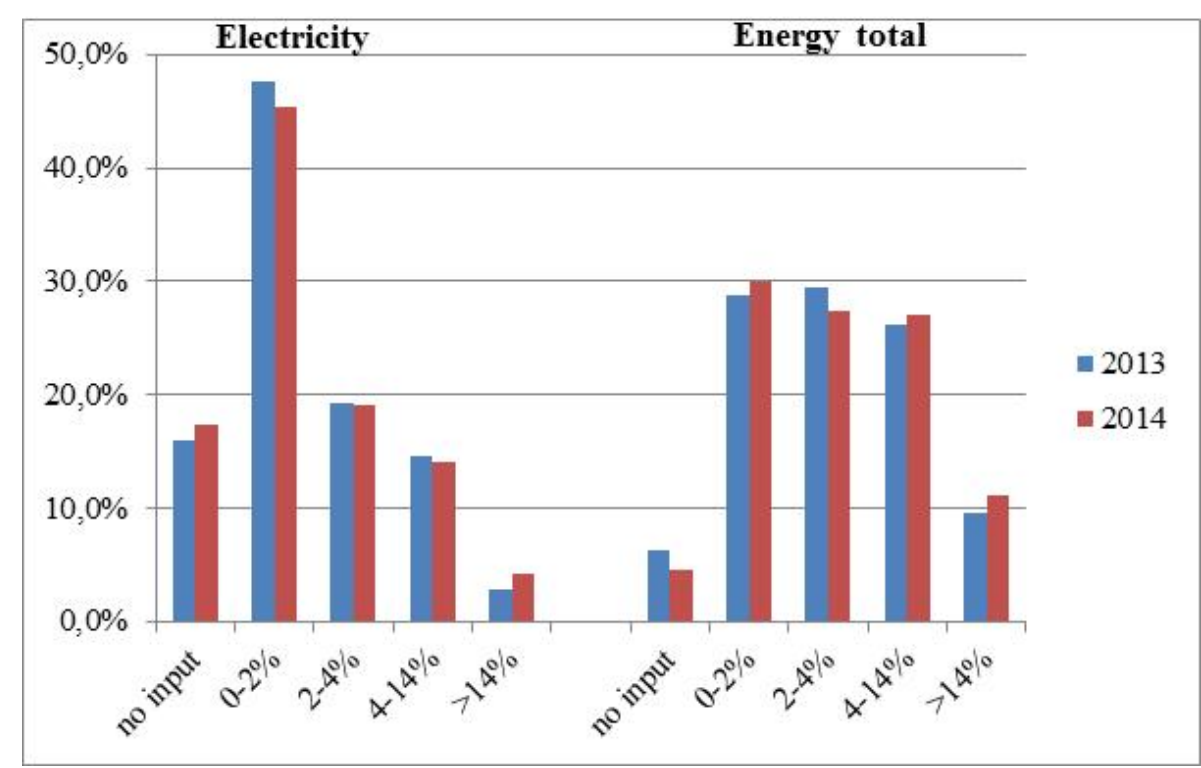

Figure 7: Share of energy costs in general, as well as the electricity costs in the overall turnover of the respondent enterprises

Source: Author's own research.

The share of electricity cost in the overall turnover however shows a strong focus of around $46 \%$ in the $0-2 \%$ range, whereas the shares of the other ranges were more or less in the same area between 14\% and 19\% (Figure 7). As in the previous case, no significant changes between 2013 and 2014 could be identified.

In order to further investigate the context, the importance of the development of the following factors during the last twelve months was analyzed: (a) the electricity prices; (b) the energy prices; (c) the variation of the energy prices; (d) the energy savings; (e) interruptions in the electricity supply; (f) interruptions in the gas supply; (g) concrete problems with the supply security; (h) the financial impact in case of production disturbance. In order to complete the analysis, the companies were asked to judge the impact of the changes in the energy system and economics on their competitiveness.

\section{The importance of the amount of electricity and energy prices}

In both years the importance of the electricity price increased, in 2013 more as in 2014 (Figure 8). This trend was discovered independently from the branch or number of employees of the companies. For the energy total prices (electricity and gas) this trend was in both years slightly stronger developed as for the electricity prices only, with a slight decrease in 2014 though compared to 2013 (Figure 8). Consequently, the amount of energy prices still is an increasingly important factor for the German enterprises. 


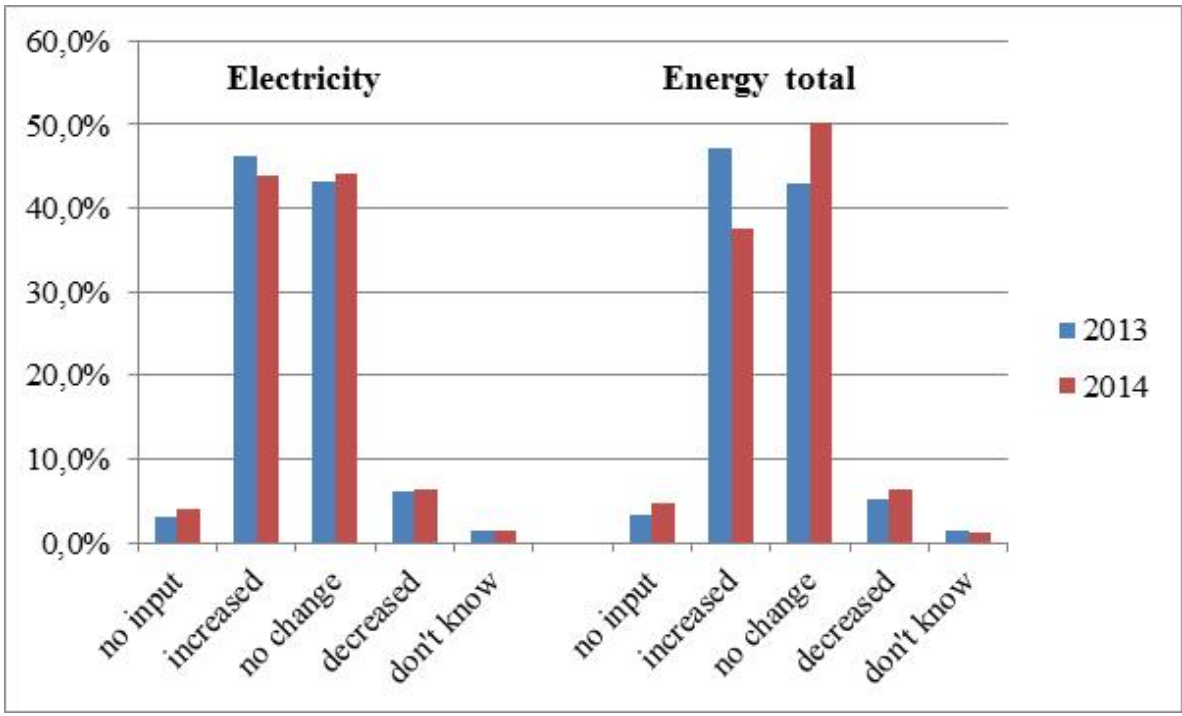

MMCKS

Figure 8: The importance of the electricity and total energy prices for the respondent enterprises

\section{Variation of energy prices}

Source: Author's own research.

The importance of the variation of energy prices (Figure ) basically reflects the development of the foreseen importance of the amounts of electricity and energy prices. This was to be expected due to the steadily increasing energy prices in both years for electricity and gas, turning out in an increasing importance in 2014 compared to 2013.

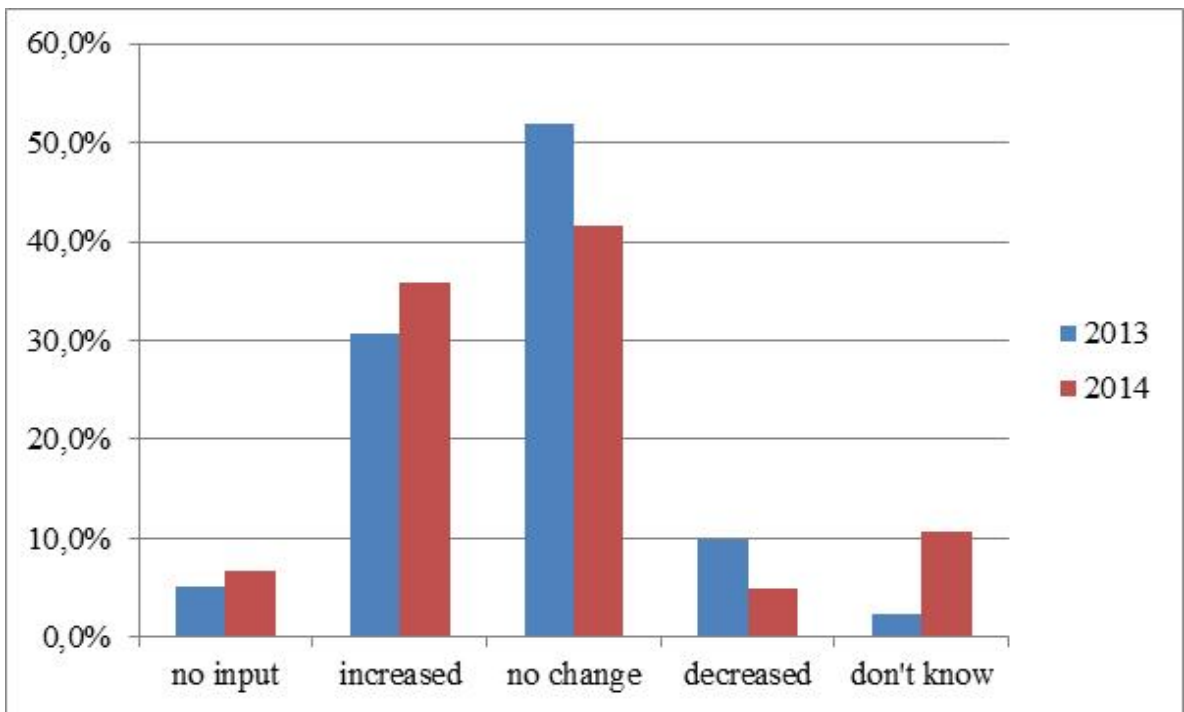

Figure 9: The importance of the variation of energy prices to the respondent enterprises

Source: Author's own research.

It also can be seen, that the level of uncertainty also increased significantly from $2.4 \%$ in 2013 to $10.7 \%$ in 2014 , which can be explained through the high level of political uncertainty before the German elections in the fall of 2014. 
MMCKS Energy savings

During the last twelve months, the energy savings turned out to be another important factor to the enterprises in Germany (Figure ). However, the trend from 2013 to 2014 shows a decreasing development. This is one effect of a high level of energy efficiency measures already been taken in the prior years, also driven by the energy efficiency regulations. Companies having implemented an energy management system according to ISO EN DIN 50001 are entitled to reimbursements of the energy and electricity tax from the government, if energy efficiency measures were installed.

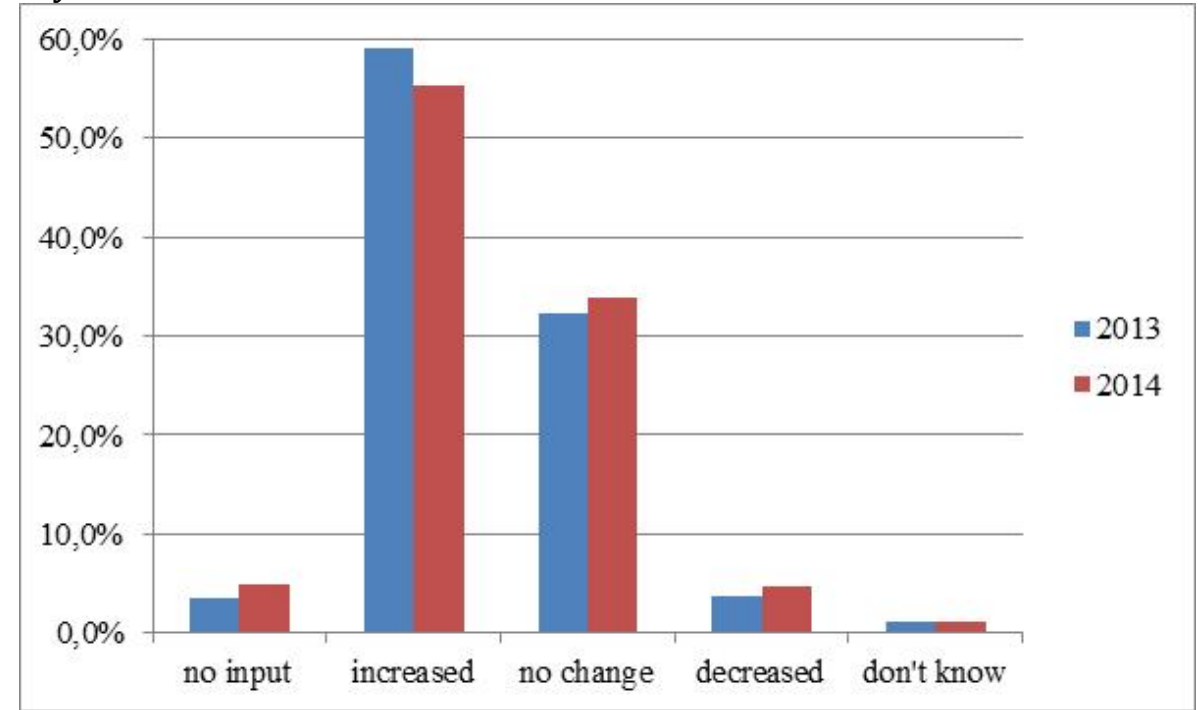

Figure 5: The importance of energy savings for the respondent enterprises

Source: Author's own research.

\section{Interruptions in the electricity and gas supply}

Changes in the development of interruptions of the electricity supply were rated mostly "no change during the last 12 months" in both years, showing a slight trend towards a decreased importance in 2014 compared to 2013 (Figure 11).

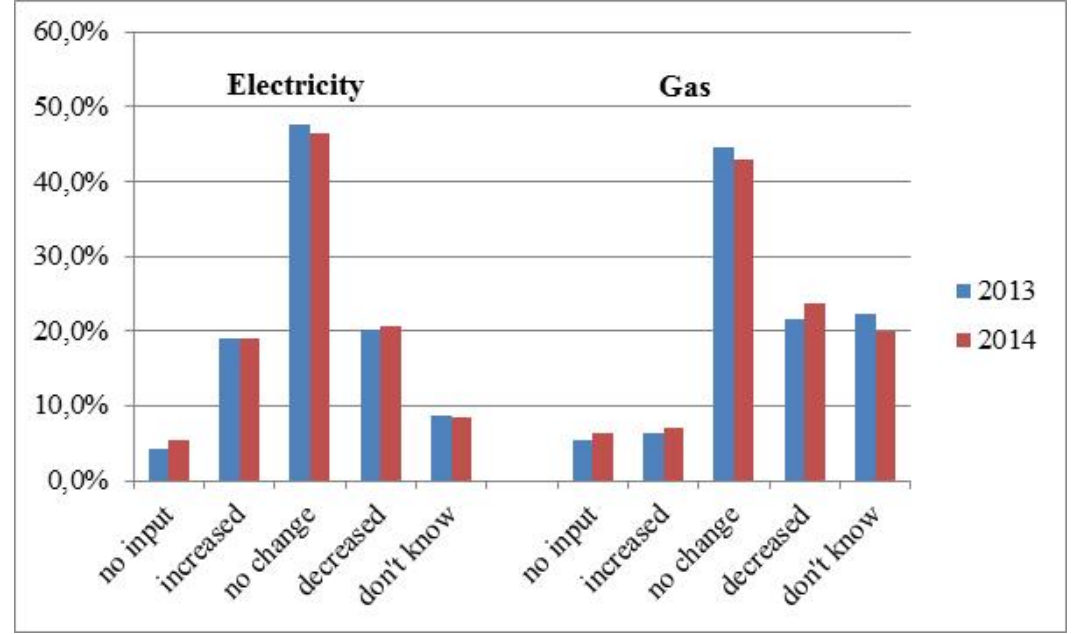

Figure 11: The importance of interruptions in electricity and gas supply for the enterprises Source: Author's own research. 
In the case of electricity however, the importance of supply interruptions are rated with $19 \%$ more important than interruptions in the gas supply (6-7\%).

Concrete problems with the supply security and the resulting financial loss

Independent from the branch or size of the company, the respondents reported in both years a very strong level of "no concrete problems" with the supply security, showing a slightly decreasing trend from 64\% in 2013 to $61.6 \%$ in 2014 (Figure ).

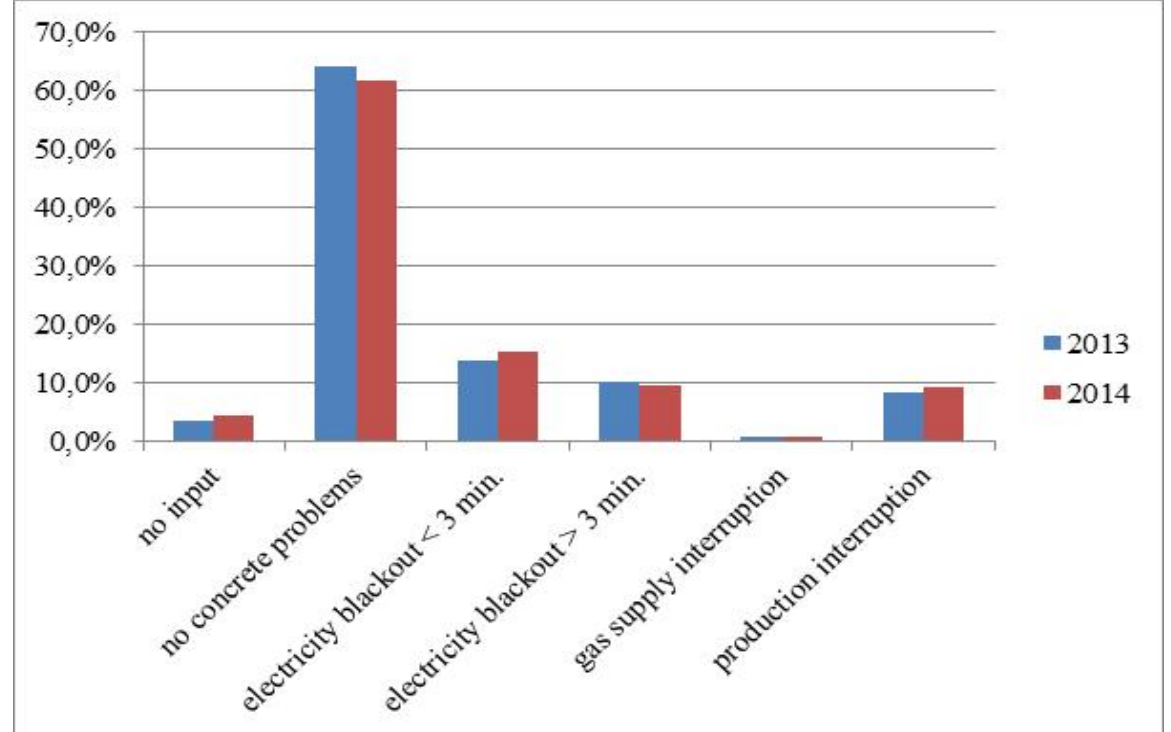

Figure 6: Concrete problems with the supply security in the surveyed enterprises

Source: Author's own research.

Whereas the number of electricity blackouts $>3$ minutes slightly decreased, a minimal higher number of electricity blackouts $<3$ minutes was reported in 2014 compared to 2013. Overall, the number of reported electricity blackouts increased from 2013 to 2014 by $0.6 \%$. The number of production interruptions slightly increased from $8.3 \%$ in 2013 to $9.1 \%$ in 2014 which can be explained by the before mentioned slightly increased number of electricity blackouts $(0.8 \%)$. Interruptions in the gas supply were in both years negligible having a constant share of $0.7 \%$. Asked about the financial impact of the production interruptions, the majority of the companies did not make any statement; either, as the data was not available, or for competitiveness reasons, which was the case in both years. However, the reluctance to provide these data was with 91\% higher in 2013 compared to 2014 with "only" 34\%. The majority of the reporting companies reported a financial loss of up to 10,000 Euro caused by production interruptions. However, due to the high rate of non-responses, this can only be an indication that there is no possibility to draw a conclusion.

\section{General judgment of the changes in energy economics during the last year}

Asked to provide their general judgment of the changes in the energy economics during the last 12 months, the majority of the respondents rated these from neutral to very negative. Comparing 2013 and 2014, the share of the positive ratings decreased by $1.5 \%$ at almost the same level as the share of the neutral ratings decreased $(1.7 \%)$. Almost at the same level these groups decreased, the level of negative feedbacks increased (negative $+1.9 \%$, very negative $+1.2 \%$ ). 


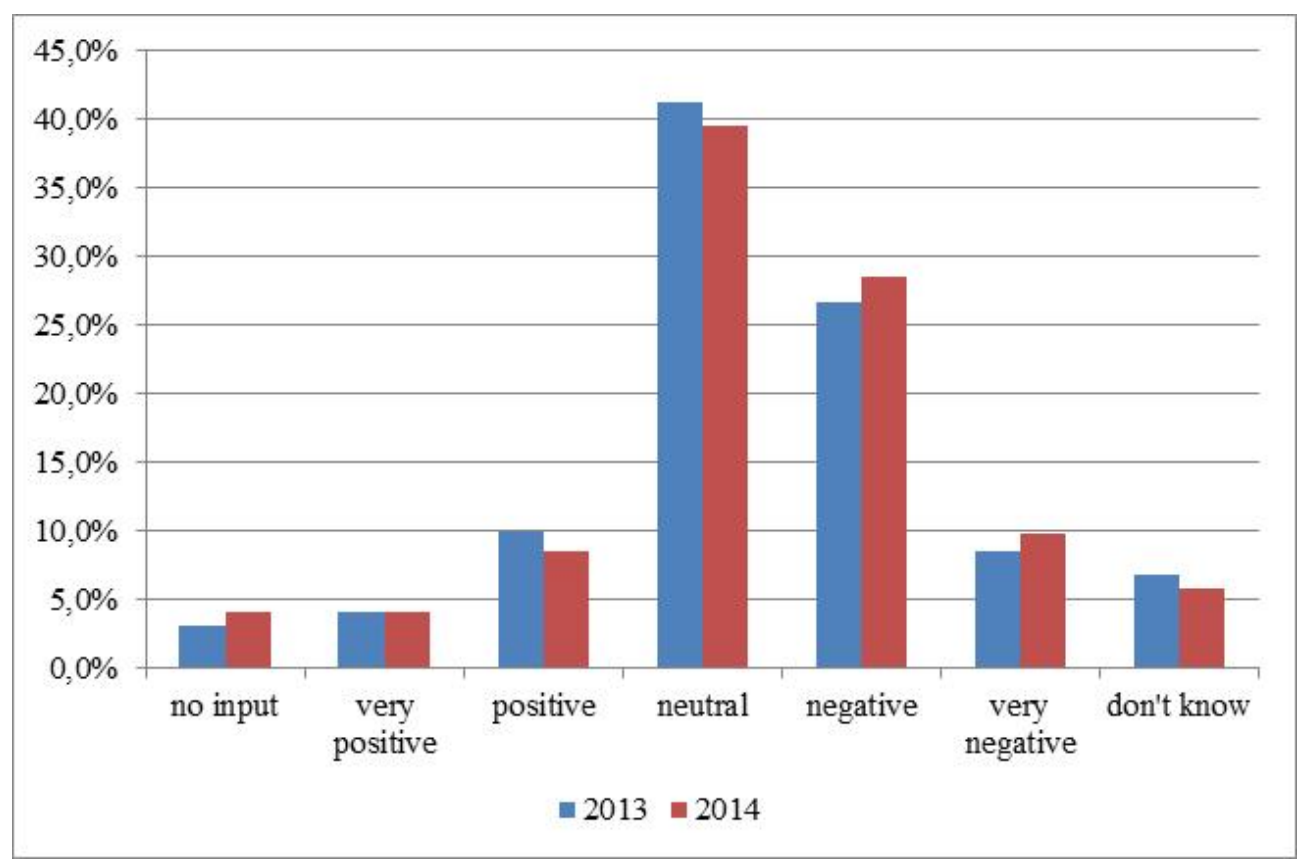

Figure 7: General judgment of the changes in the energy economics during the last twelve months

Source: Author's own research.

\section{Discussions}

Going through the analysis, several effects could be observed, which are summarized in Figure. In order to keep the path diagram clearly arranged, the arrows of the upper and lower areas of the second column complement each other. Changing the energy price level, two trends can be explored for the investigated factors: increase or decrease. A price increase (decrease) will negatively (positively) impact the share of the energy cost on the overall turnover of the enterprise. At the same time increasing (decreasing) prices will increase (decrease) the importance of fluctuating energy prices. Energy savings also become more (less) important in case the energy prices increase (decrease). 


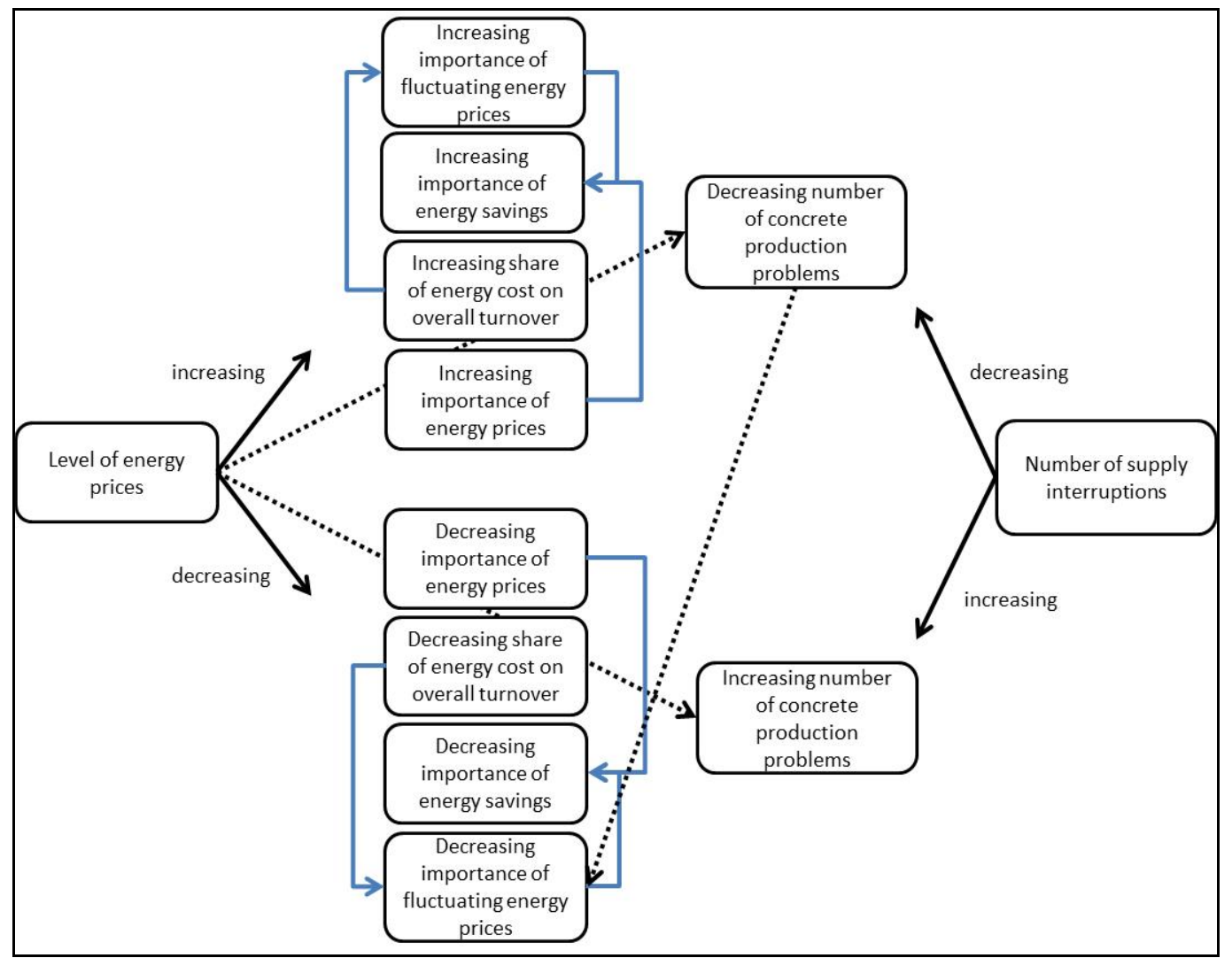

MMCKS

Figure 8: Effects of the changes in the energy economy to various factors - path diagram

Source: Author's own research.

On one hand, there are also correlations between the factors shown in column two of Figure. An increased (decreased) importance of energy prices will increase (decrease) the importance of energy savings. An increase (decrease) in the share of energy cost on the overall turnover will increase (decrease) the importance of fluctuating energy prices. On the other hand, the number of supply interruptions is not directly correlated with the factors in the second column in Figure that could be proven. However, with a decreasing (increasing) number of supply interruptions a direct correlation with decreasing (increasing) number of concrete production problems could be substantiated. A third block of correlations could be identified (see dotted lined arrows in Figure ); however, a direct connection between the two factors cannot be $100 \%$ verified.

The question whether there is a direct correlation between energy price level and the number of supply interruptions cannot be scientifically answered within this research. This is a potential topic for a further research project, as well as the question whether higher energy prices allow for the allocation of funds to keep the energy supply system in such a shape, that as a result the number of energy supply interruptions is decreasing. A third related question is whether a more stable energy supply system would allow a more balanced energy price level, hence a decreasing fluctuation of energy prices. 


\section{MMCKS Conclusions}

The analysis of the effects of the changing energy economics to enterprises in

Germany revealed that the companies are facing the highest energy price levels in Europe with an increasing trend. In this context it seems to be logical that the importance of the energy price stayed at a very high level in both 2013 and 2014. The importance of variations of the energy price however increased from 2013 to 2014, as a consequence of a volatile energy price during 2014.

The decreased importance of energy efficiency measures can be explained as one effect of a high level of energy efficiency measures already taken in the prior years, also driven by the energy efficiency regulations. Companies having implemented an energy management system according to ISO EN DIN 50001 are entitled for reimbursements of energy and electricity tax from the government, if energy efficiency measures were installed.

Supply security is not an item of concern for German enterprises. Electricity, as well as gas supply, are rated at a stable, high level which results in a more or less neutral importance change for the German enterprises throughout 2013 and 2014. As a consequence, production interruptions are also not a concern which reduces the losses caused by interruptions in the energy supply to a minimum. Most enterprises reported a financial loss of up to 10,000 Euro/year caused by production interruptions through energy supply interruptions. In most cases these were in the electricity supply.

Asked to provide a general statement on the changes in the energy economics during the last twelve months, the majority of the respondents gave in 2013 a neutral rating with a strong trend towards negative. In 2014 this trend was even stronger, with also increased shares and with very negative ratings. This needs to be seen in the context of the federal elections in Germany in fall 2014. A direct connection between the ratings and the "times of uncertainty" before elections however could not be determined.

Not all the effects of the changing energy economics to the enterprises in Germany could be analyzed in this paper. Other papers could address subjects as measures and activities the company is implementing as a result of the changes in the energy economics; the use of electricity supplied by own production capacities; measures with effects to the outside world the company is implementing as a result of the changes in the energy economy; and rating of selected political measures to make the energy supply secure, payable and environmentally friendly. In addition, a trend analysis will be further performed comparing potential changes in the answers to specific questions from calendar years 2012 to 2014 in Germany. These changes will be set in correlation with the changed political and economic environment.

\section{References}

AHK Germany-Romania (2013), Industrieeffizienz, Prozessindustrie und Logistik in Rumänien, Bucharest: Deutsch-Rumänische Industrie- und Handelskammer, available online at: www.efficiency-from-germany.info/EIE/Redaktion/ Datenmigration/marktanalyse-rumaenien-2013- industrie,property=pdf, bereich=eie,sprache=de,rwb=true.pdf (accessed March 10, 2014).

Altobelli, C.F. and Hoffmann, S. (2011). Grundlagen der Marktforschung. Konstanz, UVK Verlagsgesellschaft mbH, München. 
bdew (2013), Strompreisanalyse Mai 2013, available online at: www.bdew.de/ internet.nsf/id/123176ABDD9ECE5DC1257AA20040E368/\$file/13\%2005 \%2027\%20BDEW_Strompreisanalyse_Mai\%202013.pdf (accessed March 2, 2014).

BDI and VCI (2011), Die Steuerbelastung der Unternehmen in Deutschland - Fakten für die politische Diskussion 2011, Institut der deutschen Wirtschaft Köln Medien GmbH, Köln, available online at: www.bdi.eu/download_content/ BDI_VCI_Steuerbelastung_der_Unternehmen_2011.pdf (accessed March 10, 2014).

BET (2010), Marktplatz Energie - Kernkraftwerk Laufzeitverlängerung, available online at: www.yumpu.com/de/document/view/2944268/marktplatzenergie-10-2010-bet-aachen (accessed July 5, 2013).

BMU (2012a), Erneuerbare Energien. Motor der Energiewende, Bundesministerium für Umwelt, Berlin, Naturschutz und Rektorsicherheit, available online at: www.erneuerbare-energien.de/fileadmin/Daten_EE/Dokumente_PDFs_/ Motor_der_Energiewende_bf.pdf (accessed March 10, 2014).

BMU (2012b), Erneuerbar beschäftigt! Kurz- und langfristige Wirkungen des Ausbaus erneuerbarer Energien auf den deutschen Arbeitsmarkt, Bundesministerium für Umwelt, Naturschutz und Reaktorsicherheit, Berlin, available online at: www.bmub.bund.de/fileadmin/Daten_BMU/Pools/ Broschueren/EE_beschaeftigt_bf.pdf (accessed March 10, 2014).

BMU (2013a), Renewabley employed - impacts of the expansion of renewable energy on the German labour market, available online at: www.bmub.bund.de /fileadmin/Daten_BMU/Pools/Broschueren/erneuerbar_beschaeftigt_faltbla tt_en_bf.pdf (accessed March 10, 2014).

BMU (2013b), Aktuelle Vorhaben zum Klimaschutz und zur Umsetzung der Energiewende - Fachtagung am 13. Und 14. Juni 2013 in Berlin, available online at: www.bmub.bund.de/service/publikationen/broschuerenbestellen/\#cr14 (accessed February 17, 2014).

BMWi (2013), Energiedaten: Ausgewählte Grafiken, available online at: www.bmwi.de/BMWi/Redaktion/PDF/E/energiedaten-ausgewaehltegrafiken,property=pdf,bereich=bmwi2012,sprache=de,rwb=true.pdf (accessed March 11, 2014).

BMWi (2014), Anlage zu den „Eckpunkten für die Reform des EEG“, available online at: www.bmwi.de/BMWi/Redaktion/PDF/E/eeg-reform-eckpunkte-anlage, property=pdf,bereich=bmwi2012, sprache $=$ de,rwb=true.pdf $\quad$ (accessed February 16, 2014).

Bundesregierung (2010), Energiekonzept für eine umweltschonende, zuverlässige und bezahlbare Energieversorgung, available online at: www.bundesreg ierung.de/ContentArchiv/DE/Archiv17/_Anlagen/2012/02/energiekonzeptfinal.pdf;jsessionid=924A9A6175AF354A7BA222713D0865FD.s1t1?_ blob=publicationFile\&v=5 (accessed February 17, 2014).

Christof, K. and Pepels, W., (1999) Praktische quantitaive Marktforschung, Verlag Franz Vahlen GmbH, München.

DIHK (2013), Faktenpapier - Strompreise in Deutschland, available online at: www.ihk-energieeffizienz.de/media/upload/initiativerheinlandengerie/ imap/20121129/121129DIHKFaktenpapier_Strompreise.PDF (accessed March 14, 2014). 
MMCKS DIHK (2014), DIHK Facts, available online at: www.dihk.de/en (accessed 03 March 2014).

DLR, Fraunhofer IWES, IfnE (2010), Leitstudie 2010, available online at: www.fvee.de/fileadmin/politik/bmu_leitstudie2010.pdf (accessed March 14, 2014).

ewi (2012), Der Merit-Order-Effekt der erneuerbaren Energien - Analyse der kurzen und langen Frist, available online at: www.ewi.uni-koeln.de/fileadmin/user _upload/Publikationen/Working_Paper/EWI_WP_12_14_Merit-Order-Effektder-Erneuerbaren.pdf (accessed March 23, 2014).

Fraunhofer ISE (2013), Was kostet die Umwandlung von erneuerbaren Energien in Strom? - Studie vergleicht die Stromgestehungskosten von erneuerbaren Energien, available online at: www.ise.fraunhofer.de/de/presse-und-medien/ pdfs-zu-presseinfos/2013/presseinformation-was-kostet-die-umwandlungvon-erneuerbaren-energien-in-strom.pdf (accessed February 16, 2014).

Greenpeace, (2011), Der Plan - Deutschland ist erneurbar, available online at: www.greenpeace.de/fileadmin/gpd/user_upload/themen/energie/2011050 1-Der-Plan-Energiewende-ohne-Atom-und-Kohle.pdf (accessed February 17, 2014).

Grunwald, G. and Hempelmann, B. (2012), Angewandte Marktforschung, Oldenbourg Verlag, München.

Herrmann, A. and Homburg, C., (2000) Marktforschung, Betriebswirtschaftlicher Verlag Gabler GmbH, Wiesbaden.

Homburg, C. and Krohmer, H. ( 2009) Marketingmanagement, Gabler GWV Fachverlage $\mathrm{GmbH}$, Wiesbaden.

Kemfert, C. (2013), Kampf um Strom, Murmann-Verlag, Hamburg.

Koch, J. (2012), Marktforschung, Oldenbourg Wissenschaftsverlag GmbH, Nürnberg.

Kotler, P. (1982), Marketing Management, J.B. Metzlersche Verlagsbuchhandlung und Carl Ernst Poeschel Verlag GmbH, Stuttgart.

Marin, G. (2013). "A comparative study on the European renewable energy sources facing globalization", Management \& Marketing. Challenges for the Knowledge Society, Vol. 8, No. 4, pp. 723-746.

Ökoinstitut e. V. (2010), Erste Auswertungen der "Energieszenarien für ein Energiekonzept der Bundesregierung", available online at: www.oeko.de/publikatio nen/forschungsberichte/studien/dok/657.php (accessed February 17, 2014).

Ökoinstitut e. V., Prognos (2009), Modell Deutschland, Klimaschutz bis 2050, available online at: www.wwf.de/fileadmin/fm-wwf/Publikationen-PDF/ WWF_Modell_Deutschland_Endbericht.pdf (accessed February 17, 2014).

Olbrich, R., Battenfeld, D. and Buhr, C.-C. (2012), Marktforschung, Springer Gabler Verlag, Berlin, Heidelberg.

Prognos, ewi, gws (2010), Energieszenarien für ein Energiekonzept der Bundesregierung, BMWi, Basel, Köln, Osnabrück.

R2B (2011), Energieökonomische Analyse eines Ausstiegs aus der Kernenergie in Deutschland bis zum Jahr 2017, BDI e.V., Köln.

SRU, Sachverständigenrat für Umweltfragen, (2011), Wege zur $100 \%$ erneuerbaren Stromversorgung, Erich Schmidt Verlag GmbH \& Co. KG, Berlin.

SRU - Sachverständigenrat für Umweltfragen (2013), Shaping the electricity market of the future - special report, available online at: www.umweltrat.de 
/SharedDocs/Downloads/EN/02_Special_Reports/2012_2016/2014_02_SG_ MMCKS Shaping_the_Electricity_Market_of_the_Future.pdf?_blob=publicationFile > (accessed February 16, 2014).

statista (2012), Strompreise für Industriekunden in Europa 2012, available online at : de.statista.com/statistik/daten/studie/151260/ umfrage/strompreise-fuer-industriekunden-in-europa/ (accessed March 2, 2014).

Umweltbundesamt (2010), 2050: 100\% Strom aus erneurbaren Energien, Umweltbundesamt, Dessau-Roßlau.

Wöhe, G. (1986), Einführung in die allgemeine Betriebswirtschaftslehre, Verlag Franz Vahlen GmbH, München.

ZNES (Zentrum für nachhaltige Energiesysteme) (2011), Atomausstieg 2015 und regionale Versorgungssicherheit, Deutsche Umwelthilfe, Universität Flensburg, Flensburg/Berlin. 